\title{
THE PERCEIVED STATUS OF STRATEGIC PLANNING IN PORTUGUESE HIGHER EDUCATION INSTITUTIONS
}

\section{O status do Planejamento Estratégico nas Instituições de Educação Superior Portuguesas}

\section{Abstract}

\author{
Maria de Lourdes Machado ${ }^{1}$ \\ James Stover Taylor ${ }^{2}$ \\ Minoo Farhangmehr ${ }^{3}$
}

This study examined the status of planning within the various types of higher education institutions in Portugal. Higher education in Portugal is a binary system with university and non- university sectors. The university sector integrates public and private universities and the Catholic university. The nonuniversity sector integrates public polytechnic institutes and other establishments, the latter being private institutions. A survey methodology was used to measure perceptions from rectors and presidents within the entire system. Results suggest that institutional planning in Portuguese higher education is in its beginning phases, but there is a desire to expand that participation. While public institutions appear to be most active in attempting to establish such a process, many are doing less than strategic planning. The authors report details of the findings and make recommendations for advancing strategic planning within the system of Portuguese higher education. Keywords: strategic planning, higher education institutions, Portugal.

\section{Resumo}

Este estudo examina o estado do planejamento nas diversas instituições portuguesas de ensino superior. $\mathrm{O}$ ensino superior em Portugal é um sistema binário composto pelos setores universitário e não universitário. O sector universitário integra universidades públicas e privadas e a Universidade Católica. O setor não universitário integra os institutos politécnicos públicos e outros estabelecimentos de ensino superior, sendo estes últimos privados. Na metodologia deste estudo recorreu-se também a um questionário para estudar a percepção que os reitores e presidentes das instituições de ensino

1 Pesquisadora do CIPES (Center for Reseach on Higher Education Policies - Foudation of Protuguese Universities). Rua 1 de dezembro, 399 - 4450-227 - Matosinhos - Portugal.

2 Professor Catedrático Visitante, University do Aveiro (Portugal). Consultant to the President, Pittsburg (EEUU).

3 Professora Catedrática, School of Economics na Management. University of Minho (Portugal). 
superior têm em relação a todo o sistema de ensino superior português. Os resultados sugerem que o planejamento institucional está ainda na sua fase inicial, existindo, contudo, uma vontade em adotar este instrumento de gestão. Enquanto que as instituições públicas de ensino superior parecem mais ativas na tentativa de implementar o processo de planejamento, algumas delas não fazem, propriamente, planejamento estratégico. Os autores reportam os resultados do estudo e fazem recomendações para o desenvolvimento do planejamento estratégico no sistema de ensino superior português.

Palavras-chave: Planejamento Estratégico; Educação Superior; Instituições; Portugal.

\section{Introduction}

This project involved a nation-wide study of the extent to which Portuguese higher education institutions (HEIs) were engaged in planning. The ultimate purpose of the study was to measure the level of engagement of HEIs in institutional planning as reflected by the perceptions of rectors and presidents, who were the individuals surveyed.

The demands on higher education are putting an enormous responsibility on governance and management at the institutional level (MASSY, 1992/ 1999). Rasmussen, $(1998,38)$ states, "Much has been said about the necessity of using strategic management in the steering of the universities today. Words like 'entrepreneurial', 'innovative', 'corporate style' and 'managerialism' de, 'business-like', and 'external orientation' have been used to stress the importance of managing universities in accordance with the very dynamic societies of which they are indeed a part." (DAVIS, 1995; CLARK, 1996; GEURTS; MAASSEN, 1996; GEURTS; MAASSEN, 1996).

The prescriptive literature strongly advocates strategic planning as the key to superior performance within organizations (AUSTIN, 2002; BYRNE, 1996; BRYSON, 1988; BRYSON; ALSTON, 1996; HAHN; POWERS, 1999; HAYWARD; NCAYIYANA (2003); KELLER, 1983, 1997; PETERSON, 1992, 1999; PORTER, 1997; SHRADER, TAYLOR; DALTON, 1984).

\section{Sample and Methodology}

The Portuguese higher education system is binary, which includes universities and non-university sectors. It also includes public, private and concordatory HEIs. Public and private institutions include four categories of HEIs: public universities, public polytechnics, private universities and other establishments. Concordatory higher education is represented by only one institution, the multi-campus Catholic university. For purposes of this study and in order to protect the identity of the Catholic university, it was subsumed under the general category of public universities. 
At the time of the study, public institutions enrolled a total of 280,638 students, which constitutes $71.5 \%$ of the total enrollment in Portuguese higher education. Private HEIs enrolled another 111,653 students. Thus a total of 392,291 students were enrolled in 172 institutions within Portugal. A total of 61 HEIs responded to the questionnaire and they represented $74.77 \%$ of all students in the system. Thus, overall, $90.49 \%$ of the total students in public higher education and $55.57 \%$ of those in private higher education were represented by the HEIs in the sample. This large and highly representative sample, and especially the public sector included in the study, is at the heart and soul of defining Portuguese higher education. It therefore provides strong support for the reliability and validity of the overall sample and the generalizability of the findings.

The methodology involved interviewing prominent actors within Portuguese higher education and merging their perceptions on planning with those found in the literature. A pilot survey was tested and a final survey then developed and administered throughout Portugal. A database of responses was created and extensively analyzed using the Statistical Package for the Social Sciences (SPSS).

\section{Strategic Planning in Higher Education Institutions}

Strategic planning is a management tool, and has evolved in higher education through adaptation of practices in the business world (ROWLEY, LUJAN; DOLENCE, 1997). Several authors believe that planning is imperative for higher education institutions if they are to confront the internal and external constraints that surround them (AUSTIN, 2002; CHAFFEE, 1985; COPE, 1987; GOODSTEIN, NOLAN; PFEIFFER,1993; KELLER, 1983; MCGUINESS, 2002; NORRIS; POULTON, 1991; PETERSON, 1992, 1999; PETERSON, ET AL, 1997; ROWLEY, LUJAN; DOLENCE 1997; SCHMDTLEIN, 1990; AND STEEPLES, 1988).

However, one cannot forget the uniqueness of a higher education institution, and as stressed by Keller (1997, 163), "Strategic planning must respond to the local culture, decision-making traditions, degree of urgency, administrative vision, political skill and courage at each campus." According to Tan (1990, p.3), "The success of strategic planning should be measured by how well a given institution has accomplished its own stated institutional goals under all the internal and external environmental forces and constraints that it faces." These and related issues were examined in this study.

\section{Benefits of Strategic Planning}

Several benefits from involvement in planning appear consistently in 
the literature. These include clarification of the institution's mission, improved ability for the institution to face challenges, the capability to manage change and innovation, the capacity to support decision-making, the strengthening of leadership, help with the allocation of resources, the improvement of Total Quality Management (TQM), and overall enhancement of the ability of the institution to think and act strategically. Tan $(1990,8)$ stated that strategic planning can, “... assist... institutions in identifying potentially life-threatening adversities and how they are to be handled and overcome on a proactive and longitudinal basis." Furthermore, the author concludes that strategic planning provides institutions of higher education with the opportunity to proactively prepare for negative events that may occur in the future.

Emphasis is often placed on the environment and the challenges that higher education institutions are facing today, (MCGUINESS, 2002; PETERSON, 1999). McGuiness expands the traditional STEPP environment that examines sociological, technological, economic, political and postsecondary issues, by adding competitive, demographic and legal factors. For McGuiness, to interface with the environment, strategic decisions need to be made that will merge institutional strategies with environmental realities. His model is depicted below in Figure 1.

Figure 1 - Environmental and Institutional Challenges

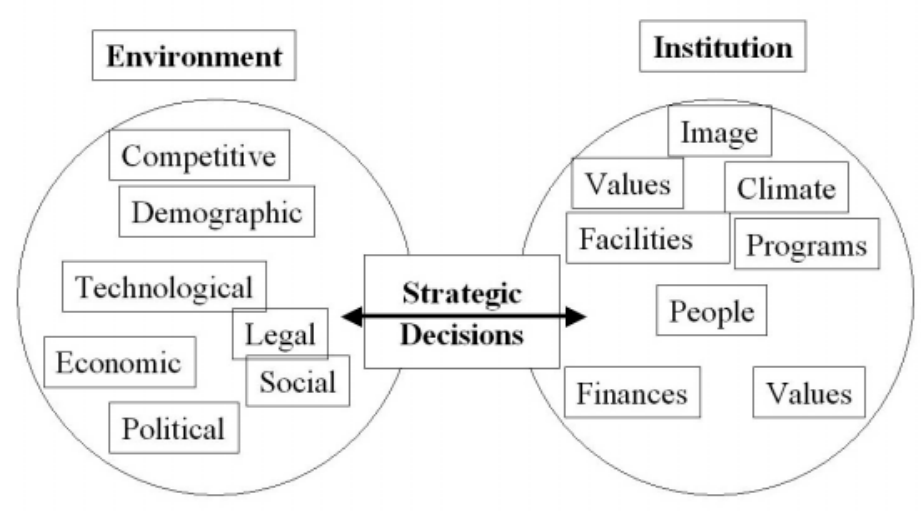

Source:McGuiness, Aims (2002). Linking Strategic Planning and Budgeting and Organizing for Change. Boulder, CO: National Center for Higher Education Management Systems.

Clark (1998); Deem (2001); and Sporn (1999) are among numerous authors that have studied the changes taking place within higher education institutions. However, the authors have different emphases. The one 
common denominator that permeates all of their discussions, however, is that institutions are in dire need of more accountability. Strategic planning is commonly advocated as the foundation upon which all meaningful change takes place within the institution (AUSTIN, 2002; BRYSON, 1988; JONES, 1999; PETERSON, 1999; SWENK, 1999).

Bryson (1988) identified the improvement in decision-making as an important benefit from planning within institutions. This, of course, implies leadership which is also pivotal to successful strategic planning (HAYWARD \& NCAYIYANA, 2003; PETERSON, 1999). The leaders of successful institutions reinforce the organizational culture as well (SIMERLY, 1987).

Benchmarking should be conducted as a part of strategic planning. Along with the process of strategic planning, institutions need to assess the external and internal environments to address the above questions by identifying and examining the best practices among competitors. Therefore, benchmarking can be a management strategy used to reach a competitive advantage (MASSY, 1999). Benchmarking is a helpful practice to improve innovation and change (AUSTIN, 2002).

Higher education institutions are often identified as unique and with ambiguous goals (BALDRIDGE, 1983, MORA, 2001). According to Tan (1990), strategic planning may encourage the clarification of existing goals and serve to develop the institution's mission, and thus reduce ambiguity. The author emphasizes the sense of positivism that is spawned and nurtured when major institutional matters are clarified, confidence and security are strengthened, and internal and external images are enhanced.

\section{Findings for the Portuguese Case}

Fifty-one of the 61 HEIs surveyed indicated that they were involved in a planning process in the broadest sense of the term. As shown in Table 1, this could be a formal institutional process, a partial process or even a process focused only on the unit level. Overall, public HEIs were more frequently engaged in a planning process. 

nal Type

Table 1 - Institutions Engaged in Some Form of Planning by Institutio-

\begin{tabular}{|c|c|c|c|c|c|c|c|}
\hline \multirow[t]{2}{*}{ INSTITUTION } & \multirow[t]{2}{*}{$\begin{array}{c}\text { NUMBER OF } \\
\text { ANSWERING HEIS }\end{array}$} & \multicolumn{2}{|c|}{$\begin{array}{l}\text { HEIS WITH } \\
\text { FORMAL PLANNING }\end{array}$} & \multicolumn{2}{|c|}{$\begin{array}{c}\text { HEIS WITH } \\
\text { PARTIAL AND/OR } \\
\text { UNIT PLANNING }\end{array}$} & \multicolumn{2}{|c|}{$\begin{array}{l}\text { TOTAL } \\
\text { HEIS WITH SOME } \\
\text { FORM OF PLAN }\end{array}$} \\
\hline & & $\mathrm{n}$ & $\%$ & $\mathrm{n}$ & $\%$ & $\mathrm{n}$ & $\%$ \\
\hline Public Universities & 13 & 11 & 84,6 & 2 & 15,4 & 13 & 100 \\
\hline Public Polytechnic & 14 & 12 & 85,7 & 2 & 14,3 & 14 & 100 \\
\hline Private Universities & 8 & 4 & 50,0 & 1 & 12,5 & 5 & 62,5 \\
\hline Other Establishments & 26 & 15 & 57,7 & 4 & 15,4 & 19 & 73,1 \\
\hline Total & 61 & 42 & 68,8 & 9 & 14,8 & 51 & 83,6 \\
\hline
\end{tabular}

Planning tends to evolve with mature institutions over time. This appears to be seen in the fact the older, public HEIs are more actively participating in planning. Planning is also a future-oriented process. Typically, the authors have observed properly conducted and successful processes look about five years into the future. As Figure 2 shows, this is most evident in the public institutions. Private universities and other establishments tended to have a shorter perspective that is often reflective of planning that is more narrowly focused on tactical, operational and budget cycle processes.

Figure 2 - Mean Years into the Future the Plan Addresses by Institutional Type

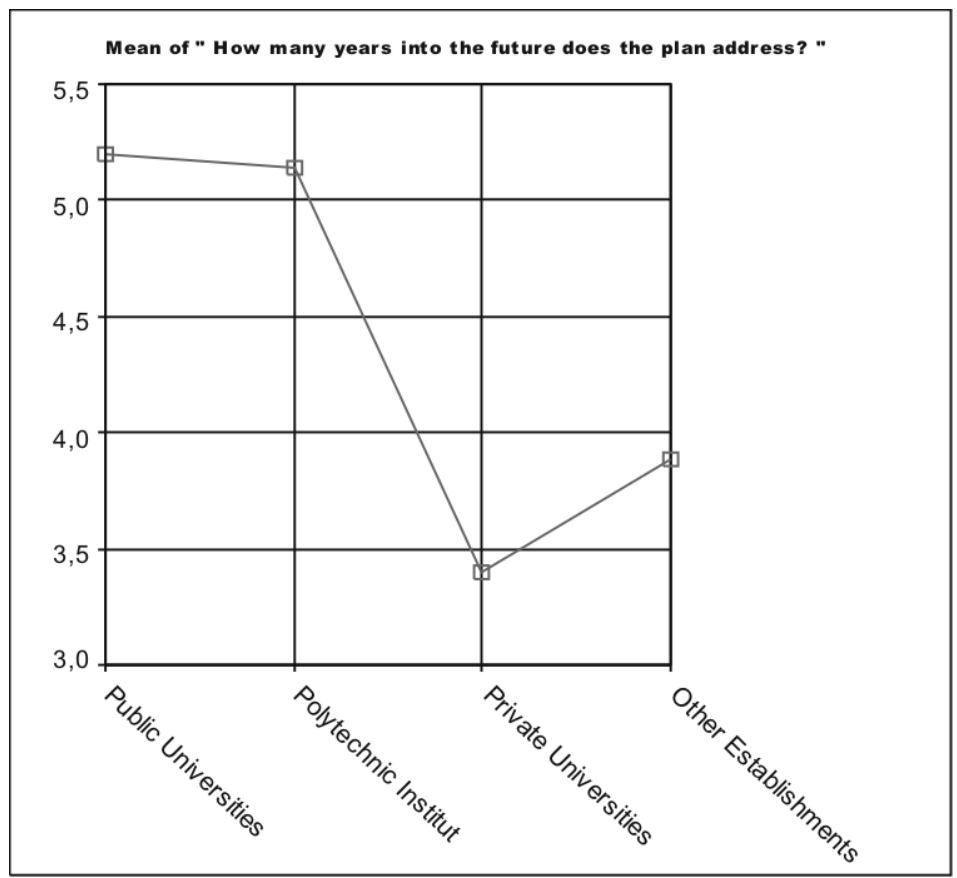


Institutions were asked if the actors organizing and contributing to the planning process were external consultants, individuals from within the HEI or a combination of both. Consultants were least often employed. The most frequent strategy was to involve only individuals from within the HEI.

Table 2 - Preferences for External Consultants or Internal Individuals in the Strategic Planning Process

\begin{tabular}{|c|c|c|c|c|c|c|}
\hline \multirow[b]{2}{*}{ Institution } & & \multicolumn{4}{|c|}{ Entities Participating } & \multirow[b]{2}{*}{ Total } \\
\hline & & $\begin{array}{c}\text { " External } \\
\text { consultants " }\end{array}$ & $\begin{array}{l}\text { "Work groups } \\
\text { with people } \\
\text { only from inside } \\
\text { the institution" }\end{array}$ & $\begin{array}{l}\text { " Work groups } \\
\text { with people } \\
\text { from inside and } \\
\text { outside of the } \\
\text { institution" }\end{array}$ & " Other " & \\
\hline \multirow{3}{*}{ Public Universities } & $n$ & 2 & 9 & 4 & 1 & 13 \\
\hline & Row $\%$ & 15,4 & 69,2 & 30,8 & 7,7 & 100,0 \\
\hline & Col \% & 25,0 & 29,0 & 19,0 & 100,0 & 25,5 \\
\hline \multirow{3}{*}{ Polytechnic Institutes } & $n$ & 3 & 8 & 6 & & 14 \\
\hline & Row \% & 21,4 & 57,1 & 42,9 & & 100,0 \\
\hline & Col \% & 37,5 & 25,8 & 28,6 & & 27,5 \\
\hline \multirow{3}{*}{ Private Universities } & $n$ & & 2 & 3 & & 5 \\
\hline & Row \% & & 40,0 & 60,0 & & 100,0 \\
\hline & Col \% & & 6,5 & 14,3 & & 9,8 \\
\hline \multirow{3}{*}{ Other Establishments } & $n$ & 3 & 12 & 8 & & 19 \\
\hline & Row \% & 15,8 & 63,2 & 42,1 & & 100,0 \\
\hline & Col \% & 37,5 & 38,7 & 38,1 & & 37,3 \\
\hline \multirow{3}{*}{ Total } & n & 8 & 31 & 21 & 1 & 51 \\
\hline & Row \% & 15,7 & 60.8 & 41,2 & 2.0 & 100,0 \\
\hline & Col \% & 100.0 & 100.0 & 100.0 & 100.0 & 100.0 \\
\hline
\end{tabular}

A planning process can impart many influences upon an institution. HEIs were asked what they observed from the fact planning was in place at their institution. Foremost was the observation that the rector or president was primarily responsible for planning, suggesting evidence of a top-down model. This was followed by perceptions that the process was reviewed as circumstances dictated, strategic decisions were made by the leadership team and it supported the development of the institutional mission. The full results are shown in Table 3.

The authors have observed over many years and continents that the above comments generally reflect a perception on the part of the leadership that they are essentially governing the planning process. This coincides with the tendency to have top-down planning. The red flag that must be raised here is that participation, communication and personal ownership at all levels within the institution in the planning process are critical to its success. Leaders are deluding themselves if they believe they can successfully implement stra- 
tegic planning without institution-wide support. Without followers, leaders have no one to lead.

Table 3 - Influential Factors from the Planning Process for All Institutional Types

\begin{tabular}{|c|c|c|c|c|c|c|c|c|c|c|c|c|c|}
\hline \multirow{2}{*}{$\begin{array}{l}\text { "Given your experience with and knowledge of the last } \\
\text { plan developed, indicate the extent to which you agree } \\
\text { with each of the following statements" }\end{array}$} & \multicolumn{2}{|c|}{$\begin{array}{l}\text { I agree } \\
\text { totallly }\end{array}$} & \multicolumn{2}{|c|}{$\begin{array}{c}\text { I agree in } \\
\text { part }\end{array}$} & \multicolumn{2}{|r|}{ tral } & \multicolumn{2}{|c|}{$\begin{array}{c}\text { I disagree in } \\
\text { part }\end{array}$} & \multicolumn{2}{|c|}{$\begin{array}{c}\text { I disagree } \\
\text { totallly }\end{array}$} & $\begin{array}{c}\text { Does Not } \\
\text { Anolly }\end{array}$ & $\begin{array}{c}\text { No } \\
\text { Response }\end{array}$ & Iotal \\
\hline & $n$ & $\%$ & $n$ & $\%$ & $n$ & $\%$ & $n$ & $\%$ & $\mathrm{n}$ & $\%$ & $\%$ & $\%$ & $\%$ \\
\hline $\begin{array}{l}\text { " the process of strategic planning affects or has affected } \\
\text { the mission of the institution " }\end{array}$ & 21 & 41,2 & 16 & 31,4 & & 9,8 & & 3, & & 7 & 5 & & 100 \\
\hline $\begin{array}{l}\text { "the mission of the institution was defined / reviewed as a } \\
\text { result of planning " }\end{array}$ & 13 & 25,5 & 24 & 47,1 & & 5,9 & & 7, & & 5 & 3 & 3 & 100 \\
\hline $\begin{array}{l}\text { "the planning process helped in the definition of the } \\
\text { vision of the institution" }\end{array}$ & 24 & 47,1 & 24 & 47,1 & & 2, & & 2 , & & & 2 & & 100 \\
\hline $\begin{array}{l}\text { " the department / person who coordinates the planning } \\
\text { process only has a role as "facilitator " " }\end{array}$ & 5 & 9,8 & 17 & 33,3 & & 7,8 & & 7, & 1 & 29 & 9 & 2 & 100 \\
\hline $\begin{array}{l}\text { "the office of rector/president has the main responsibility } \\
\text { for the planning process" }\end{array}$ & 36 & 70,8 & & 15,7 & & 5,9 & & 2, & & 3 & & 2 & 100 \\
\hline $\begin{array}{l}\text { "the planning process was communicated to the entire } \\
\text { institution " }\end{array}$ & 32 & 62,7 & 13 & 25,5 & & 2,0 & & 5, & & & 3 & & 100 \\
\hline "the plan was developed by an interactive process " & 21 & 41,2 & 21 & 41,2 & & 2,0 & & 5, & & 2 & 7 & & 100 \\
\hline $\begin{array}{l}\text { "the plan has been reviewed as situations or conditions } \\
\text { change " }\end{array}$ & 32 & 62,7 & 10 & $19, \mathrm{Q}$ & & 3,9 & & 5, & & & 7 & & 100 \\
\hline $\begin{array}{l}\text { "people at all levels of the institution have been involved } \\
\text { in the planning " }\end{array}$ & 6 & 11,8 & 23 & 45,1 & & 9,8 & & 13, & & 7 & 9 & 2 & 100 \\
\hline $\begin{array}{l}\text { "strategic decisions have been made by the office of the } \\
\text { rector/ president " }\end{array}$ & 26 & 51,0 & 20 & 39,2 & & 2, & & 3, & & 3 & & & 100 \\
\hline
\end{tabular}

Clearly, an effort to engage in institutional strategic planning will only ultimately succeed if the institution realizes positive benefits from the effort. While perceptions from rectors and presidents was essentially positive, one of the key components of a legitimate strategic planning process that was meaningfully absent from HEI processes was the use of key performance indicators (KPIs). The use of KPIs provides indisputable data on accomplishments. It is critical to the overall integrity of the planning process as an important part of the evaluation of the ongoing strategic planning process.

Agreement was generally strong within all institutional types that the process of planning provided institutional benefits. The most prevalent perceptions in order were that planning helped individuals understand institutional issues better, assisted in the determination of priorities, helped in the identification of the HEIs comparative advantages with its competition, assisted in the internal strengthening of the HEI, offered a mechanism for better internal coordination and provided a means of identifying institutional strengths and weaknesses. When totally and partly agree categories are combined, it is also found that HEIs noted the process helped in the development of activities that met the needs of the community. On the negative ledger, the two most prevalent responses were that it did not facilitate performance measures of performance and it failed to inform the HEI about the external environment. Total findings for this item appear in Table 4. 


\section{Types}

Table 4 - Benefits from the Planning Process for All Institutional

\begin{tabular}{|c|c|c|c|c|c|c|c|c|c|c|c|c|c|c|c|c|}
\hline \multirow{3}{*}{$\begin{array}{l}\text { " In relation to the planning process, } \\
\text { indicate the extent to which you agree or } \\
\text { disaqree with the following statements " } \\
\text { "It helped us to know the institution better" }\end{array}$} & \multicolumn{2}{|c|}{ I acree totallv } & \multicolumn{2}{|c|}{1 aaree in vart } & \multicolumn{2}{|c|}{ Neutral } & \multicolumn{2}{|c|}{$\begin{array}{c}\text { I disagree in } \\
\text { Dart }\end{array}$} & \multicolumn{2}{|c|}{$\begin{array}{c}\text { I disagree } \\
\text { totally }\end{array}$} & \multicolumn{2}{|c|}{ I do not know } & \multicolumn{2}{|c|}{ No Response } & \multicolumn{2}{|c|}{ Total } \\
\hline & $\mathrm{n}$ & $\%$ & $\mathrm{n}$ & $\%$ & $\mathrm{n}$ & $\%$ & $\mathrm{n}$ & $\%$ & $\mathrm{n}$ & $\%$ & $\mathrm{n}$ & $\%$ & $\mathrm{n}$ & $\%$ & $\mathrm{n}$ & $\%$ \\
\hline & 38 & 74,5 & 9 & 17,6 & 3 & 5,9 & 1 & 2,0 & & & & & & & 51 & 100,0 \\
\hline $\begin{array}{l}\text { "It helped us become conscious of the } \\
\text { comparative advantages " }\end{array}$ & 26 & 51,0 & 22 & 43,1 & 3 & 5,9 & & & & & & & & & 51 & 100,0 \\
\hline $\begin{array}{l}\text { "It contributed to the internal strengthening } \\
\text { of the institution " }\end{array}$ & 24 & 47,1 & 22 & 43,1 & 3 & 5,9 & & & & & 2 & 3,9 & & & 51 & 100,0 \\
\hline $\begin{array}{l}\text { "It helped in the development of activities } \\
\text { that met the needs of the community " }\end{array}$ & 14 & 27,5 & 28 & 54,9 & 6 & 11,8 & 1 & 2,0 & & & 1 & 2,0 & 1 & 2,0 & 51 & 100,0 \\
\hline $\begin{array}{l}\text { "It contributed to the integration of all } \\
\text { activities consistent with the mission of the } \\
\text { institution " }\end{array}$ & 17 & 33,3 & 24 & 47,1 & 4 & 7,8 & 4 & 7,8 & & & 1 & 2,0 & 1 & 2,0 & 51 & 100,0 \\
\hline $\begin{array}{l}\text { "It helped us to know the external } \\
\text { environment better " }\end{array}$ & 12 & 23,5 & 23 & 45,1 & 9 & 17,6 & 3 & 5,9 & 2 & 3,9 & & & 2 & 3,9 & 51 & 100,0 \\
\hline $\begin{array}{l}\text { "It helped us to identify our institutional } \\
\text { weaknesses and problems " }\end{array}$ & 23 & 45,1 & 25 & 49,0 & 2 & 3,9 & & & 1 & 2,0 & & & & & 51 & 100,0 \\
\hline "It helped us create changes " & 19 & 37,3 & 27 & 52,9 & 3 & 5,9 & & & 1 & 2,0 & 1 & 2,0 & & & 51 & 100,0 \\
\hline $\begin{array}{l}\text { "It helped motivate the people within the } \\
\text { institution " }\end{array}$ & 14 & 27,5 & 25 & 49,0 & 9 & 17,6 & & & 1 & 2,0 & 2 & 3,9 & & & 51 & 100,0 \\
\hline $\begin{array}{l}\text { " It made better internal coordination of the } \\
\text { institution possible " }\end{array}$ & 25 & 49,0 & 19 & 37,3 & 4 & 7,8 & & & 1 & 2,0 & 2 & 3,9 & & & 51 & 100,0 \\
\hline $\begin{array}{l}\text { "It contributed to cohesion between the } \\
\text { different levels of management " }\end{array}$ & 15 & 29,4 & 24 & 47,1 & 9 & 17,6 & & & 1 & 2,0 & 2 & 3,9 & & & 51 & 100,0 \\
\hline $\begin{array}{l}\text { "It made an increase of creativity in the } \\
\text { institution possible " }\end{array}$ & 11 & 21,6 & 26 & 51,0 & 11 & 21,6 & 2 & 3,9 & & & 1 & 2,0 & & & 51 & 100,0 \\
\hline $\begin{array}{l}\text { " It allowed for better optimization of } \\
\text { resources " }\end{array}$ & 18 & 35,3 & 24 & 47,1 & 7 & 13,7 & & & 2 & 3,9 & & & & & 51 & 100,0 \\
\hline $\begin{array}{l}\text { "It facilitated performance measures of } \\
\text { each unit in accordance with already } \\
\text { defined and specific objectives " }\end{array}$ & 14 & 27,5 & 19 & 37,3 & 9 & 17,6 & 4 & 7,8 & 2 & 3,9 & 2 & 3,9 & 1 & 2,0 & 51 & 100,0 \\
\hline $\begin{array}{l}\text { " It provided for more stability in an } \\
\text { environment of constant change " }\end{array}$ & 15 & 29,4 & 24 & 47,1 & 8 & 15,7 & 3 & 5,9 & & & 1 & 2,0 & & & 51 & 100,0 \\
\hline $\begin{array}{l}\text { "Generally, it brought more benefits than } \\
\text { costs for the institution" }\end{array}$ & 20 & 39,2 & 24 & 47,1 & 5 & 9,8 & 1 & 2,0 & 1 & 2,0 & & & & & 51 & 100,0 \\
\hline "It lead to transparent management " & 19 & 37,3 & 19 & 37,3 & 9 & 17,6 & 2 & 3,9 & 1 & 2,0 & 1 & 2,0 & & & 51 & 100,0 \\
\hline $\begin{array}{l}\text { "It determined priorities for the future of the } \\
\text { institution " }\end{array}$ & 31 & 60,8 & 15 & 29,4 & 3 & 5,9 & & & & & 2 & 3,9 & & & 51 & 100,0 \\
\hline
\end{tabular}

Planning is never without problems and challenges. Institutions were quite clear in their identification of problems, with financial, physical, human and technological resources being the largest barrier. See Table 5 for the findings on all HEI types.

Table 5 - Problems Affecting Planning for All Institutional Types

\begin{tabular}{|c|c|c|c|c|c|c|c|c|c|c|c|c|c|c|c|c|}
\hline \multirow{2}{*}{$\begin{array}{l}\text { "Which of the following problems are affecting the } \\
\text { process of planning in your institution in terms of its } \\
\text { development and implementation?" }\end{array}$} & \multicolumn{2}{|c|}{ Totally } & \multicolumn{2}{|c|}{ Strongly } & \multicolumn{2}{|c|}{ Moderately } & \multicolumn{2}{|c|}{ Slightly } & \multicolumn{2}{|c|}{ Not at All } & \multicolumn{2}{|c|}{$\begin{array}{c}\text { Does Not } \\
\text { Apply }\end{array}$} & \multicolumn{2}{|c|}{ No Response } & \multicolumn{2}{|c|}{ Total } \\
\hline & $\mathrm{n}$ & $\%$ & $\mathrm{n}$ & $\%$ & $\mathrm{n}$ & $\%$ & $\mathrm{n}$ & $\%$ & $\mathrm{n}$ & $\%$ & $\mathrm{n}$ & $\%$ & $\mathrm{n}$ & $\%$ & $\mathrm{n}$ & $\%$ \\
\hline "Lack of engagement of the senior administrators " & 1 & 2,0 & 3 & 5,9 & 8 & 15,7 & 14 & 27,5 & 18 & 35,3 & 6 & 11,8 & 1 & 2,0 & 51 & 100,0 \\
\hline "Absence of communication " & & & 7 & 13,7 & 14 & 27,5 & 16 & 31,4 & 8 & 15,7 & 5 & 9,8 & 1 & 2,0 & 51 & 100,0 \\
\hline " Lack of information " & 1 & 2,0 & 5 & 9,8 & 12 & 23,5 & 20 & 39,2 & 7 & 13,7 & 5 & 9,8 & 1 & 2,0 & 51 & 100,0 \\
\hline "Tendencies for excessively fast changes " & 1 & 2,0 & 4 & 7,8 & 20 & 39,2 & 16 & 31,4 & 7 & 13,7 & 2 & 3,9 & 1 & 2,0 & 51 & 100,0 \\
\hline $\begin{array}{l}\text { " Lack of motivation of involved staff in its } \\
\text { implementation " }\end{array}$ & 2 & 3,9 & 3 & 5,9 & 11 & 21,6 & 17 & 33,3 & 12 & 23,5 & 5 & 9,8 & 1 & 2,0 & 51 & 100,0 \\
\hline " Lack of necessary resources Financial " & 9 & 17,6 & 16 & 31,4 & 16 & 31,4 & & & 6 & 11,8 & 4 & 7,8 & & & 51 & 100,0 \\
\hline " Lack of necessary resources Physical " & 6 & 11,8 & 13 & 25,5 & 19 & 37,3 & 6 & 11,8 & 4 & 7,8 & 3 & 5,9 & & & 51 & 100,0 \\
\hline " Lack of necessary resources Human " & 6 & 11,8 & 16 & 31,4 & 18 & 35,3 & 3 & 5,9 & 5 & 9,8 & 3 & 5,9 & & & 51 & 100,0 \\
\hline " Lack of necessary resources Tecnological " & 6 & 11,8 & 11 & 21,6 & 19 & 37,3 & 5 & 9,8 & 7 & 13,7 & 3 & 5,9 & & & 51 & 100,0 \\
\hline $\begin{array}{l}\text { "Changes in the environment unfavorable to the } \\
\text { implementation of the plan " }\end{array}$ & 1 & 2,0 & 11 & 21,6 & 13 & 25,5 & 15 & 29,4 & 7 & 13,7 & 4 & 7,8 & & & 51 & 100,0 \\
\hline "Absence of an adequate implementation process" & & & 6 & 11,8 & 7 & 13,7 & 16 & 31,4 & 14 & 27,5 & 7 & 13,7 & 1 & 2,0 & 51 & 100,0 \\
\hline " Development of conflicts " & 1 & 2,0 & 6 & 11,8 & 7 & 13,7 & 17 & 33,3 & 16 & 31,4 & 4 & 7,8 & & & 51 & 100,0 \\
\hline "Lack of time" & 1 & 2,0 & 9 & 17,6 & 15 & 29,4 & 13 & 25,5 & 8 & 15,7 & 4 & 7,8 & 1 & 2,0 & 51 & 100,0 \\
\hline " Inconsistencies in the planning process " & & & 3 & 5,9 & 7 & 13,7 & 5 & 9,8 & 9 & 17,6 & 5 & 9,8 & 22 & 43,1 & 51 & 100,0 \\
\hline " Other " & & & 2 & 3,9 & 1 & 2,0 & & & 1 & 2,0 & 2 & 3,9 & 45 & 88,2 & 51 & 100,0 \\
\hline
\end{tabular}


The Kruskal-Wallis One-Way Analysis of Variance (by Ranks) is a nonparametric analysis of variance test by ranks for two or more independent groups. It is used in this study to test for significant differences between the four independent institutional types. The test found statistically significant differences between HEI types for three problems: financial resources $(\mathrm{H}=8.164$, $\mathrm{p}<043)$; human resources $(\mathrm{H}=8.618, \mathrm{p}<035)$; and technological resources $(\mathrm{H}=7.998, \mathrm{p}<.046)$.

Based on a Principle Components Factor Analysis, Figure 3 shows the mean importance values for the four factors identified: lack of resources, absence of communication, conflict and fast changes, and lack of time and a non-conducive environment. Notable differences appear between public universities and the other HEI types. Conflict and fast change is seen as important to all HEIs except the public universities. The absence of communication was strongly noted by all institutions except private universities. Overall, the most visible contrast is between public and private universities.

Figure 3 - Mean Importance of Factors Impacting Planning by Institutional Type

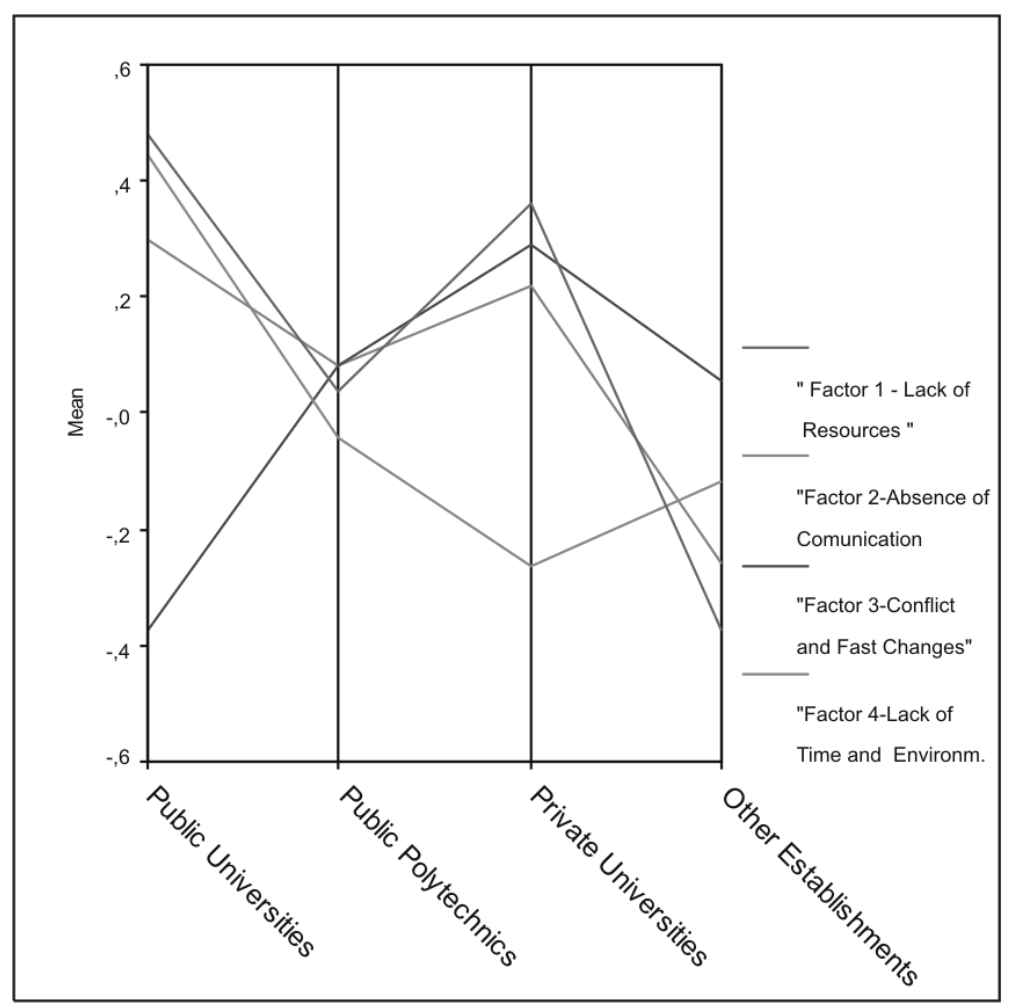




\section{Strategic Planning Institutions}

Based on the full array of specific questions in the questionnaire, a determination was made as to the number of HEIs that were legitimately engaged in a strategic process of planning. While many HEIs professed to be so engaged, questions about key components of such a process based on the literature suggested many were, in fact, doing less than strategic planning. While it is easy to proclaim strategic planning for an institution in general terms, later indications of lack of involvement in many of the critical elements of such a process led the authors to conclude that only 24 of 61 HEIs in the study were doing strategic planning. Findings reveal that the majority of public universities, private universities and other establishments were doing less than strategic planning. Only public polytechnics had a small majority of HEIs that met the criteria for strategic planning. See Table 6.

Table 6 - Engagement in Strategic Planning by Institutional Type

Institution * Strategic Planning Institutions Crosstabulation

\begin{tabular}{|c|c|c|c|c|}
\hline \multirow[b]{2}{*}{ Institution } & & \multicolumn{2}{|c|}{ Strategic Planning Institutions } & \multirow[b]{2}{*}{ Total } \\
\hline & & $\begin{array}{c}\text { Strategic } \\
\text { Planning } \\
\text { Institutions }\end{array}$ & $\begin{array}{c}\text { Institutions Not } \\
\text { Engaged in } \\
\text { Strategic Planning }\end{array}$ & \\
\hline \multirow{4}{*}{$\begin{array}{c}\text { Public } \\
\text { Universities }\end{array}$} & $n$ & 4 & 9 & 13 \\
\hline & Row \% & 30,8 & 69,2 & 100,0 \\
\hline & Column \% & 16,7 & 24,3 & 21,3 \\
\hline & Total\% & 6,6 & 14,8 & 21,3 \\
\hline \multirow{4}{*}{$\begin{array}{l}\text { Polytechnic } \\
\text { Institutes }\end{array}$} & $n$ & 8 & 6 & 14 \\
\hline & Row \% & 57,1 & 42,9 & 100,0 \\
\hline & column \% & 33,3 & 16,2 & 23,0 \\
\hline & Total\% & 13,1 & 9,8 & 23,0 \\
\hline \multirow{4}{*}{$\begin{array}{c}\text { Private } \\
\text { Universities }\end{array}$} & $\pi$ & 3 & 5 & 8 \\
\hline & Row \% & 37,5 & 62,5 & 100,0 \\
\hline & Columाm to & $T 2,5$ & 73,5 & 13,1 \\
\hline & Tolal 10 & 4,9 & 8,2 & 13,1 \\
\hline \multirow{4}{*}{$\begin{array}{c}\text { Other } \\
\text { Establishments }\end{array}$} & $n$ & y & $T 1$ & 26 \\
\hline & Row \% & 34,0 & 05,4 & 100,0 \\
\hline & 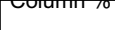 & 37,5 & 45,9 & 42,0 \\
\hline & Totan & 14,8 & 27,9 & 42,6 \\
\hline \multirow{4}{*}{ Total } & & $2-1$ & 01 & \\
\hline & & 39,5 & 00,1 & $+\infty, 0$ \\
\hline & 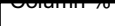 & 100,0 & 100,0 & TU⿺⿻一, \\
\hline & & כדינד & 00,1 & 0,0 \\
\hline
\end{tabular}


For the $39.3 \%$ of all institutions surveyed that qualified for having a strategic planning process the process seems to have provided five major benefits: better understanding of the HEI, priorities identification, improved internal coordination, institutional strengthening and increased awareness of institutional comparative advantages. Clearly, advantages can be seen from the opinions of the rectors and presidents of the HEIs surveyed. It is also clear that a component of this is institutional sensitivity to the internal and external variables that impact it. This, in fact, is one of the greatest benefits from engaging in strategic planning. See Figure 4. ning HEIs

Figure 4 - Benefits from the Planning Process from Strategic Plan-

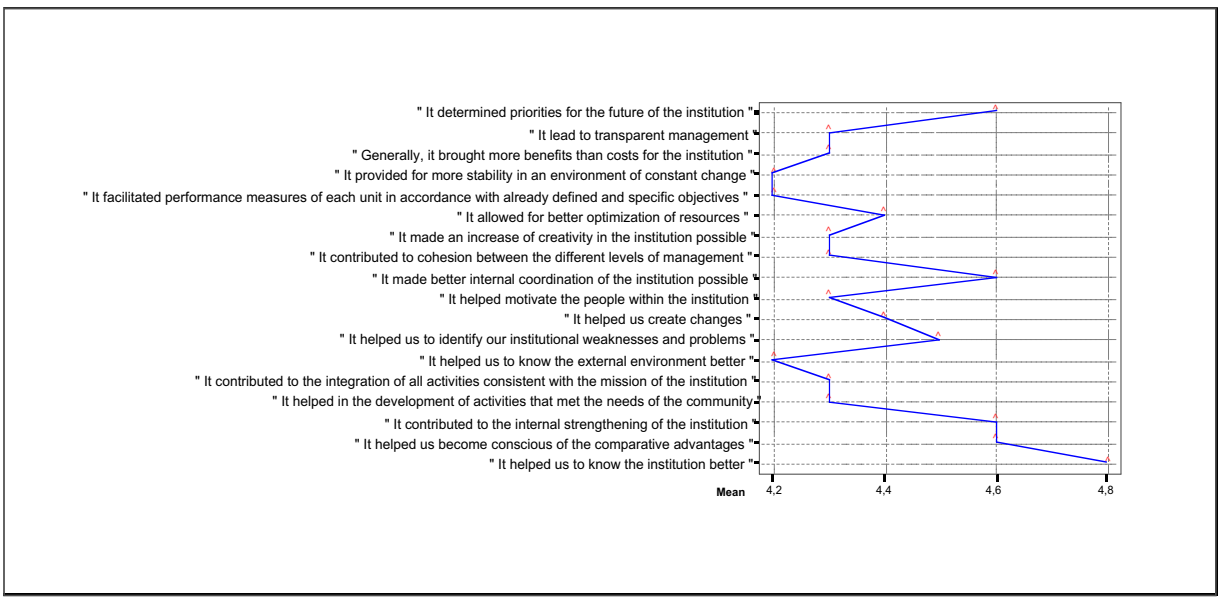

\section{Discussion: Looking Ahead}

Overall, it would appear the legitimate involvement of Portuguese higher education in the process of strategic planning is embryonic, at best. Some notable examples of sound processes are clearly in existence, which is encouraging and suggests further advancements are possible in the future. However, there are several restraining factors that will be noted below. Generally, public institutions are attempting strategic planning more than private institutions. Their ability to actually create a strategic planning process is, however, insufficient at the moment. Considerable evidence from the questionnaire (including open comments) suggests many "other establishments" hold the process in disdain and have no interest in pursuing it. Indications for the other three institutional types suggest a legitimate desire to understand and pursue strategic planning more vigorously. 
Thus, the first restraint impeding the advancement of strategic planning in Portuguese HEIs is a lack of understanding of the process. It seems clear from the findings, that many institutions are making honest efforts to engage in strategic planning, but are unsure how to proceed. Outside consultants would probably benefit these institutions, but they will most likely benefit from assistance in identifying qualified individuals or organizations to assist them in finding the right ones.

Beyond the limitations of the individual institutions is a second more pervasive restraint. The Portuguese higher education system needs more strategic focus, direction and guidance. Without a system-wide strategic plan for higher education, the institutions are left to their own devices to develop strategies. This results in independent efforts by individual institutions to engage in planning. Certainly, internal self-assessments and advancements are possible through such a process, but no integration among and between HEIs that can only come from a coordinated system effort is possible. Institutions cannot be expected to identify and pursue individual distinctiveness and their role within the overall higher education system unless the system itself provides an umbrella process under which each HEI can become meaningfully integrated. Institutional planning in isolation and without system support is far less productive. It becomes a much more internal process of identifying strengths and weaknesses, and setting goals for institutional improvement without the external perspective that is the hallmark of strategic planning. A disconnected national system for higher education planning should be avoided. The only solution is for the Ministry to orchestrate a master plan with full participation of all HEIs and other higher education actors in Portugal. As a member of the European Union several factors are challenging the Portuguese higher education system. In particular the Bologna Declaration, which is to be fully implemented in 2010. It is time for higher education to step out of perpetuating traditions over advancements, and embrace change. Strategic planning is a legitimate vehicle for doing exactly that.

\section{References}

AUSTIN, W.J. Strategic Planning for Smart Leadership. Stillwater, OK: New Forums, 2002.

BALDRIDGE, J.V. Organizational Characteristics of Colleges and Universities. In: _ _ ; Deal (Eds.). The Dynamics of Organizational Change in Education. Berkeley: McCutchan, 1983.

.V.; Deal, T.E. The Basics of Change in Educational Organizations. In: 
., DEAL, T.E.; Ingols, C. (Eds.). The Dynamics of Organizational Change in Education. Berkeley, CA: McCutchan, 1983.

BRY SON, J. M. Strategic planning for Public and Nonprofit Organizations. San Francisco, CA: Jossey Bass, 1988.

; Alston, F. K. Creating and Implementing Your Strategic Plan. San Francisco: Jossey-Bass, 1996.

HAHN, W.; POWERS, T. The Impact of Planning Sophistication and Implementation on Firm Performance. The Journal of Business and Economic Studies, v. 5, p. 19-35, 1999.

CHAFFE, E. E. Three Models of Strategy. Academy of Management Review, v.10, n. 1, p. 89-98, 1985.

CLARK, Burton. Creating Entrepreneurial Universities: Organizational Pathways of Transformation. Oxford: IAU: Pergamon, 1998.

COPE, R. Opportunity from Strength: Strategic Planning Clarified with Case Examples. ASHE-ERIC Higher Education Reports, Reportn. 8. Washington, D.C.: American Association of Higher Education, 1987.

DEEM, R. Globalisation, New Managerialism, Academic Capitalism and Entrepreneurialism in Universities: Is the Local Dimension Still Important?' Comparative Education, v. 37, n. 1, p. 7-20, 2001.

GEURTS, P.; MAASSEN, P. Academic and Institutional Governance. In: MAASSEN, P.; van VUGHT, F. (Eds.). Inside Academia: New Challenges for the Academic Profession. Utrecht, NE: CHEPS, 1996.

GOODESTEIN, LD., NOLAN, T.; PFEIFFER, J. Applied Strategic Planning: A Comprehensive Guide. New York: McGraw-Hill, 1993.

HAYWARD, F.; NCAYIAYANA, D. Strategic Planning: A Guide for Higher Education Institutions. South Africa: Centre for HigherEducation Transformation, 2003.

JONES, Dennis. Expanding Information and Decision-Support Systems. In: PETERSON, M. (Ed.). ASHE Reader on Planningand Institutional Research. Needham Heights, MA: Pearson Custom Publishing., 1999. p. 464-476

KELER, G. Academic Strategy: The Management Revolution in American Higher Education. Baltimore, MD: Johns Hopkins University Press, 1983. M.; Dill, D,1997.

Examining What Works in Strategic Planning, In : . Peterson, 
METS, L. and Associates (Eds.). Planning and Managing for a Changing Environment: A Handbook on Redesigning Postsecondary Institutions. San Francisco: Jossey-Bass.

MASSY, W. Improvement Strategies for Administration and Support Services. In: PETERSON, M. (Ed.). ASHE Reader on Planning and Institutional Research. Needham Heights, MA: Pearson Custom, 1999. p. 418-438.

McGUINESS, Aims. Linking Strategic Planning and Budgeting and Organizing for, Change. Boulder, $\mathrm{CO}$ : National Center for Higher Education Management Systems, 2002.

MORA, J-G. Governance and Management in the New University. Tertiary Education and Management, v.7, p. 95-110, 2001.

NORRIS, Donald M.; POULTN, Nick. L. A Guide for New Planners. Ann Arbor, MI: Society for College and University Planning, 1991.

PETERSON, M. Contextual Planning: The Challenge of the $21^{\text {st }}$ Century. Paper presented at the EAIR. Annual Forum. Brussels, Belgium, 1992.

. Using Contextual Planning to Transform Institutions. In: Peterson, M., (Ed.). ASHE Reader on Planning and Institutional Research. Needham Heights, MA: Pearson Custom Publishing. 1999. p. 127-157.

PETERSON, M.; Dill, D., METS, L.and Associates (Eds.). Planning and Managing for a Changing Environment: A Handbook on Redesigning Postsecondary Institutions. San Francisco: Jossey-Bass, 1997.

PORTER, M.E. Creative Advantages. Executive Excellence, v.14, p. 17-18, 1997.

RASMUSSEN, J.G. The Chief and the Ordinary Professor: Decentralized and Informal Relationships as Preconditions for Strategic Managementin Universities. Tertiary Education and Management, v.4, p. 38-47, 1998.

ROWLEY, D.; LUJAN; H.; DOLENCE, M. Strategic Change in Colleges and Universities: Planning to Survive and Prosper. San Francisco: Jossey-Bass, 1997.

SCHIMDTLEIN, F. Responding to Diverse Institutional Issues: Adapting Strategic Planning Concepts,. New Directions for Institutional Research, v.67, p. 83-93,1990.

SIMERLY, R.G. The Strategic Planning Process: Seven Essential Steps. In: Simerly, R.G.; Associates (Eds.). Strategic Planning and Leadership in Continuing Education. San Francisco: Jossey Bass, 1987. 
SPORN, B. Towards More Adaptive Universities: Trends of Institutional Reform in Europe. Higher Education in Europe, v.24, n. 1, p. 23-33, 1999.

Shrader, C.B., Taylor, L. \& Dalton, D.R. (1984). "Strategic Planning and Organizational Performance: A Critical Appraisal," Journal of Management, 10, 149-171.

Steeples, D.W. Concluding Observations. In: Steeples, D.W. (Ed.). Successful Strategic Planning Case Studies. San Francisco: Jossey-Bass, 1988. p. 99-104.

SWENK, J. Planning Failures: Decision Cultural Clashes. The Review of Higher Education, v. 23, n.1,p. 1-21, 1999.

TAN, D.L Strategic Planning in Higher Education: Varying Definitions, Key Characteristics, Benefits, Pitfalls and Good Approaches. Conference of the Southwest Society for College and University Planning., 1990.

Recebido em 30/10/03 Aprovado em 28/11/03 